\title{
Inactivation of $\mathbf{f} 2$ coliphage in municipal effluent by the use of various disinfectants
}

\author{
BY H. HAJENIAN AND M. BUTLER \\ University of Surrey, Guildford, Surrey
}

(Received 20 July 1979)

\begin{abstract}
SUMMARY
Bromine chloride, chlorine and peracetic acid inactivated f2 coliphage in effluent but in order to achieve $99.99 \%$ inactivation the three disinfectants were required at about 1,10 and $100 \mathrm{mg} / \mathrm{l}$ respectively. The activity of chlorine was halved by the presence of added organic matter, whereas bromine chloride and peracetic acid were very little affected. When a second successive dose of virus was added to the reaction mixture, the virus was inactivated only by peracetic acid despite the fact that in the chlorine-treated effluent residual chlorine was detected. The addition of a second dose of disinfectant inactivated residual virus in the same way as the first dose.
\end{abstract}

\section{INTRODUCTION}

The inactivation of viruses in waste-water effluents has been studied by several investigators (Lothrop \& Sproul, 1969; McKee, Brokaw \& McLaughlin, 1960; Olivieri, Donovan \& Kawata, 1971; Shuval et al. 1966; Warriner, 1967). Where disinfection of effluents is practised chlorine is mainly used because it is the cheapest and easiest disinfectant to handle and its chemistry is very well documented (White, 1972). However, there are disadvantages in its use for effluents as opposed to clean waters, because it reacts with the nitrogenous matter present in the effluent resulting in the formation of large amounts of stable and persistent mono- and dichloramines, as well as other potentially toxic chlorinated compounds (Painter, 1971). Thus in order to achieve a residual of free chlorine, the chlorine demand of the effluent has to be satisfied, a treatment known as 'break-point' chlorination (Palin, 1950).

Alternative disinfectants have been proposed and some of them used. Ozone is one of the more widely tested, although more commonly used for the disinfection of drinking water supplies (Coin, Hannoun \& Gomella, 1964; Evison, 1972; Perlman, 1969) than for effluents (Katzenelson \& Biederman, 1976; Pavoni et al. 1972). The fact that ozone does not introduce a disinfecting residual and is costly to manufacture has restricted its use. Another disadvantage is that there is a large ozone demand by turbid effluents.

The use of halogens other than chlorine has been restricted to small, confined water bodies - for instance, bromine is used for the disinfection of swimming 
pools (Brown, McLean \& Nixon, 1963; Taylor \& Johnson, 1974), and iodine is used for emergency disinfection of drinking water (Chang \& Morris, 1953). Bromine has the advantage of forming bromamines in the effluent which are relatively more virucidal than chloramines (Smith, 1978). Iodine has the advantage of not reacting with ammonia at all. However, both halogens have proved to be very expensive for municipal purposes.

Mills (1973) suggested bromine chloride as a potent disinfectant for effluents and it was tested by Keswick et al. (1977) who found it to be more virucidal than chlorine. Another halogen compound, chlorine dioxide, is also reported to have considerable activity against viruses in water (Tifft et al. 1977) but has not been tried in effluents.

Peracetic acid is known to be virucidal (Kline \& Hull, 1960; Sprössig \& Mücke, 1969), but there is only one report of its use as a waste-water disinfectant (Meyer, 1975) which was for the decontamination of abattoir effluents.

In this paper the activities of three disinfectants against one virus under standardized conditions were compared.

\section{f2 coliphage}

\section{MATERIAL AND METHODS}

The method for the propagation and assay of the male-specific coliphage f2 is described elsewhere (Balluz, Butler \& Jones, 1978).

\section{Effluent}

The collection and storage of the effluent from the Guildford Sewage Treatment Plant and its characteristics have been described previously (Hajenian \& Butler, 1980).

\section{Experimental procedure}

The apparatus and methods are described in a previous report (Hajenian \& Butler, 1980). All experiments were conducted at $15^{\circ} \mathrm{C}$ and $\mathrm{pH}$ 6. In the chlorine and bromine experiments the $\mathrm{pH}$ of the effluent, usually around $7 \cdot 5$, was adjusted to 6.0 before the start of an experiment. With peracetic acid, however, this adjustment was not necessary, because the $\mathrm{pH}$ of the effluent was brought down to and stayed at about $5 \cdot 8$ after the addition of the acid.

\section{Disinfectants}

(a) Chlorine gas (BDH Air Products) was bubbled into distilled water until a concentration of $5000-7000 \mathrm{mg} / \mathrm{ml}$ was obtained (determined iodometrically).

(b) Bromine chloride was prepared by bubbling chlorine gas into liquid bromine (Hopkins \& Williams Ltd) in a pressurized vessel until the weight of the contents increased by $44 \%$ (Mills, 1975). $\mathrm{BrCl}$ was stored frozen in liquid nitrogen $\left(-180^{\circ} \mathrm{C}\right.$ ) to prevent evaporation. One $\mathrm{ml}$ of $\mathrm{BrCl}$ dissolved in $100 \mathrm{ml}$ cold distilled de-ionized water yielded a concentration of $7000 \mathrm{mg} / \mathrm{l}$ (determined iodometrically).

Appropriate amounts of both these halogen stock solutions, $(a)$ and $(b)$, were 


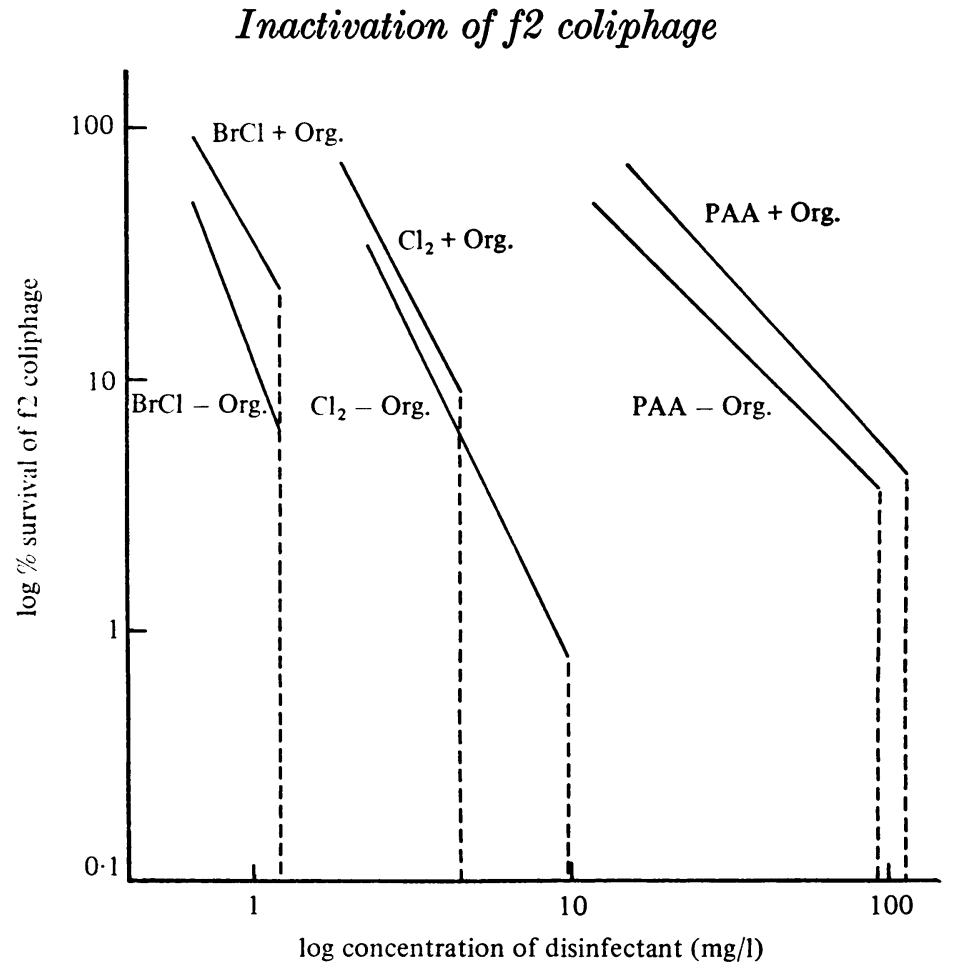

Fig. 1. Inactivation of $\mathrm{f} 2$ coliphage in effluent with bromine chloride, chlorine and peracetic acid, in the presence and absence of $22 \mathrm{mg} / \mathrm{l}$ added organic matter, at $\mathrm{pH} 6$ and $15^{\circ} \mathrm{C}$.

dispensed into the experimental vessels and their final concentrations were determined by the DPD method (Palin, 1957).

(c) Peracetic acid (35\% aqueous solution; Phase Separation Ltd) was prepared as a $1 \%$ working solution by dilution in distilled water at $4{ }^{\circ} \mathrm{C}$ and stored at that temperature. Titration of peracetic acid in the experimental vessels was carried out as described by Sulley \& Williams (1962).

\section{Analysis of data}

The inactivation data obtained were subjected to least-square analysis. The regression lines related the log percentage inactivation of virus to disinfectant residual. The same analysis was also used to calculate the threshold value of disinfectant required to inactivate $99.99 \%$ of the virus.

\section{RESULTS}

A comparison of the disinfecting abilities of chlorine, bromine chloride $(\mathrm{BrCl})$ and peracetic acid (PAA) in effluent (Fig. 1) revealed that for $99.99 \%$ inactivation of the $\mathrm{f} 2$ coliphage $\mathrm{BrCl}$ and $\mathrm{PAA}$, unlike chlorine, were little affected by the presence of additional organic matter. It was also shown that $\mathrm{BrCl}$ was active at one-tenth the concentration of chlorine whereas PAA was required at ten times that of chlorine on a weight per volume basis. There was a linear negative correlation between the amount of disinfectant and extent of inactivation (Fig. 1, 


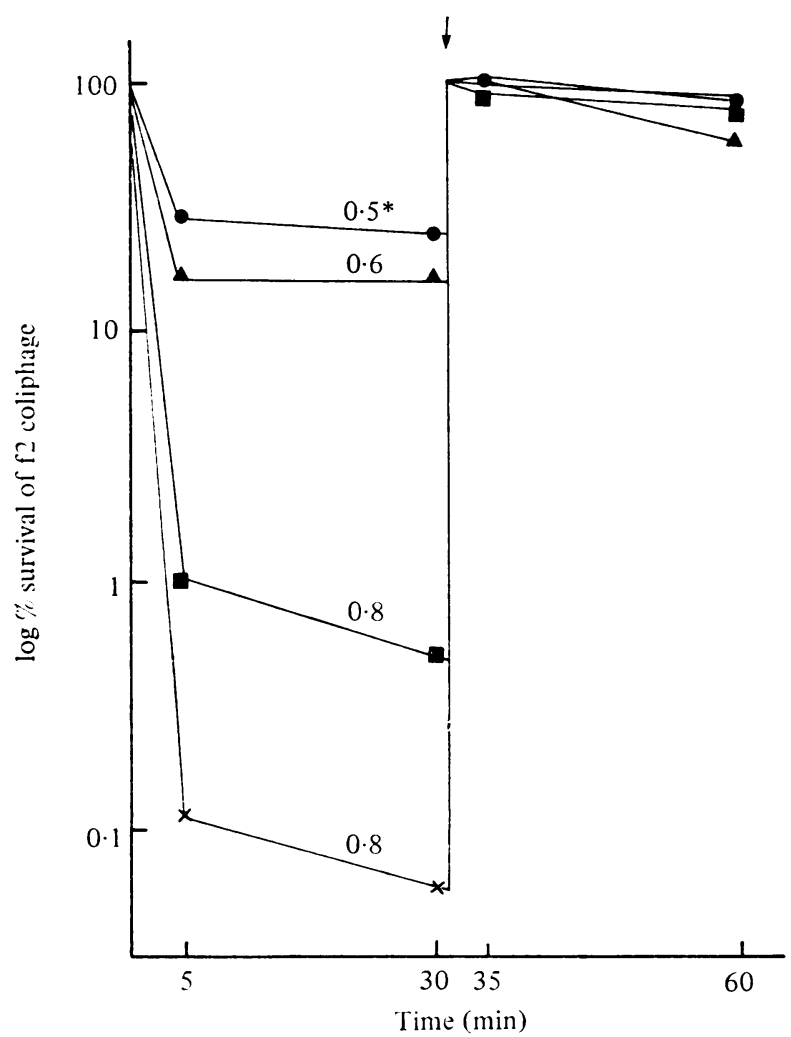

Fig. 2. Chlorination of two successive doses of $\mathrm{f} 2$ coliphage in effluent at $\mathrm{pH} 6$ and $15^{\circ} \mathrm{C}$. Arrow indicates time when second dose of $\mathrm{f} 2$ was added. ${ }^{*} \mathrm{Chlorine}$ residual (mg/l).

solid lines) up to a certain threshold value of disinfectant, above which $99.99 \%$ inactivation was achieved (Fig. 1, dotted lines).

The protection afforded to the effluent by residual disinfectant was studied by adding a second dose of $\mathrm{f} 2$ coliphage. Chlorine, despite the presence of a residual of 'free chlorine' (Fig. 2) or 'combined chlorine' (Fig. 3) was unable to inactivate added virus. However, in contrast, PAA fully retained its capacity to inactivate a second dose of virus (Fig. 4). Furthermore, unlike chlorine, there was very little loss of measurable PAA throughout the experiment.

The addition of a second dose of any one of the three disinfectants achieved the same percentage of inactivation of virus as obtained with the original dose (Figs. 5, 6 and 7). In the case of two-step chlorination and bromination the final residual obtained at 65 minutes was about the same as at 30 minutes; in other words, there was again a demand for the halogen, whereas with peracetic acid there was an increased residual observed after the addition of the second dose (Fig. 7) which confirmed that there was no demand on the acid. 


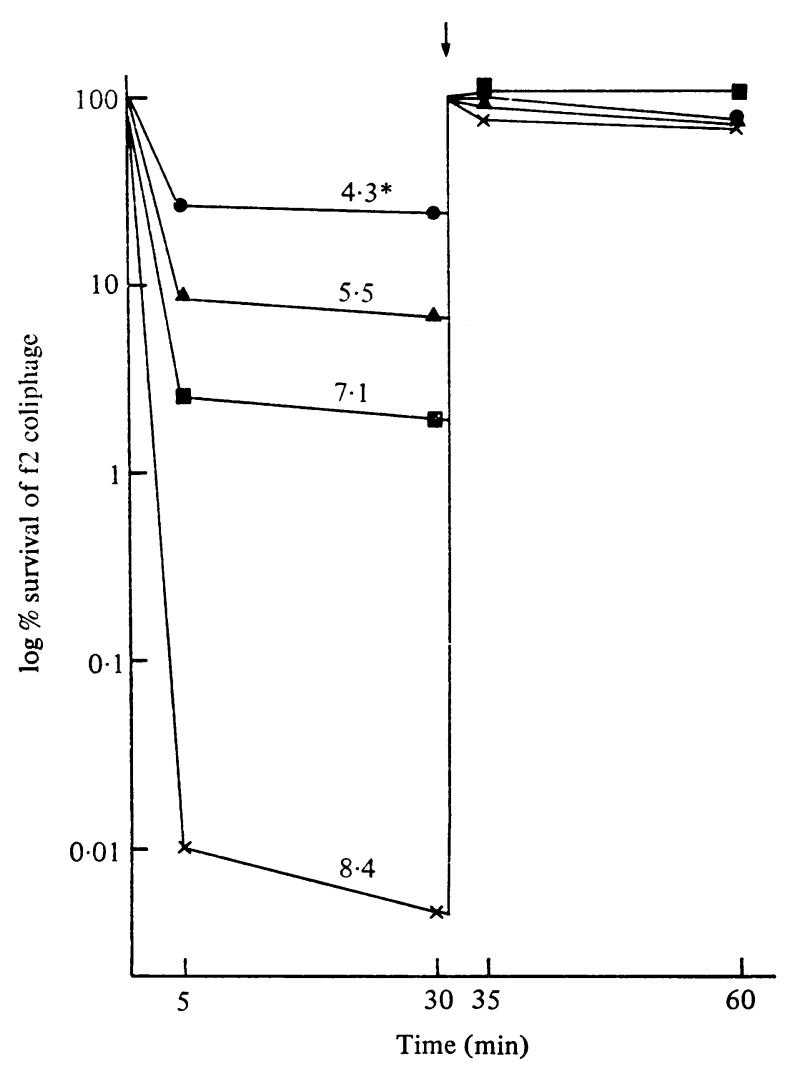

Fig. 3. Chlorination of two successive doses of $\mathrm{f} 2$ coliphage in effluent at $\mathrm{pH} 6$ and $15^{\circ} \mathrm{C}(22 \mathrm{mg} / \mathrm{l}$ organic matter in the medium $)$. Arrow indicates time when second dose of $\mathrm{f} 2$ was added. ${ }^{*}$ Chlorine residual $(\mathrm{mg} / \mathrm{l})$.

\section{DISCUSSION}

The disinfection of effluents with chlorine has usually been conducted by the 'break-point' procedure in order to take account of the chlorine demand of the system. However, the concentration of the nitrogenous compounds in an effluent may be so highly variable that a clearcut break-point concentration could not be predicted. Furthermore, requirement for chlorine would also be influenced by the undefined and variable organic matter present in the effluent (Painter, 1971). In this respect it was interesting to observe that neither bromine chloride nor peracetic acid was much affected by the presence of added organic matter, and this was not the only advantage in the use of these two disinfectants in contrast to chlorine. For instance, bromine chloride hydrolyses to produce $90 \% \mathrm{HOBr}$, the active form (Mills, 1973), at $\mathrm{pH}$ values around neutrality, which is the normal $\mathrm{pH}$ of the effluent. Chlorine, on the other hand, produces only $19 \% \mathrm{HOCl}$ at around neutrality, so that acidification of effluent to about $\mathrm{pH} 6 \cdot 0$ would be desirable in order to achieve at least $90 \%$ hypochlorous acid, the active form. The addition of peracetic acid resulted in a drop of the $\mathrm{pH}$ to just below $6 \cdot 0$, and it would have been interesting to examine the disinfecting activity of this acid in conjunction with chlorine. In certain cases, like abattoir effluents, hospital 


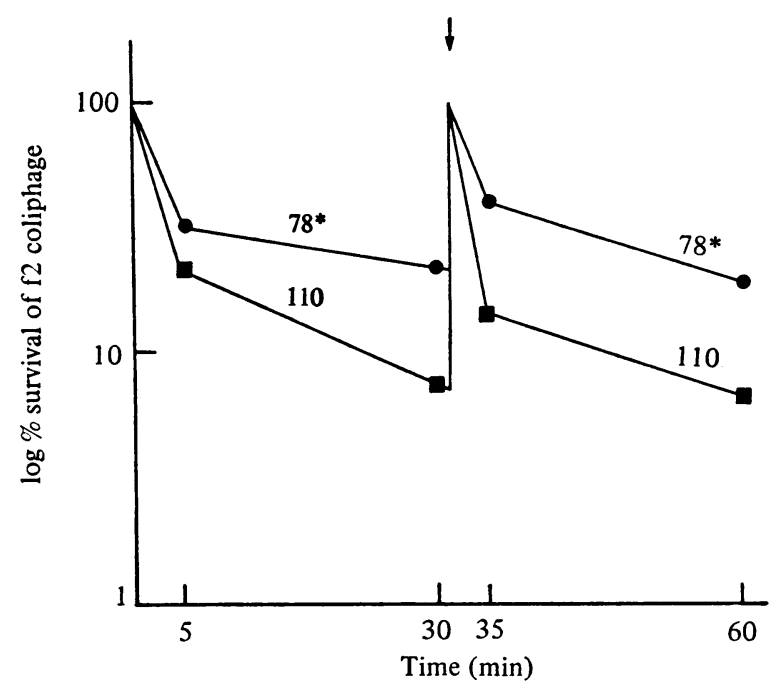

Fig. 4. Disinfection of two successive doses of $\mathrm{f} 2$ coliphage in effluent with peracetic acid at $\mathrm{pH} 7.6$ and $15^{\circ} \mathrm{C}(22 \mathrm{mg} / 1$ organic matter in the medium). Arrow indicates time when second dose of $\mathrm{f} 2$ was added. *Peracetic acid residual (mg/l).

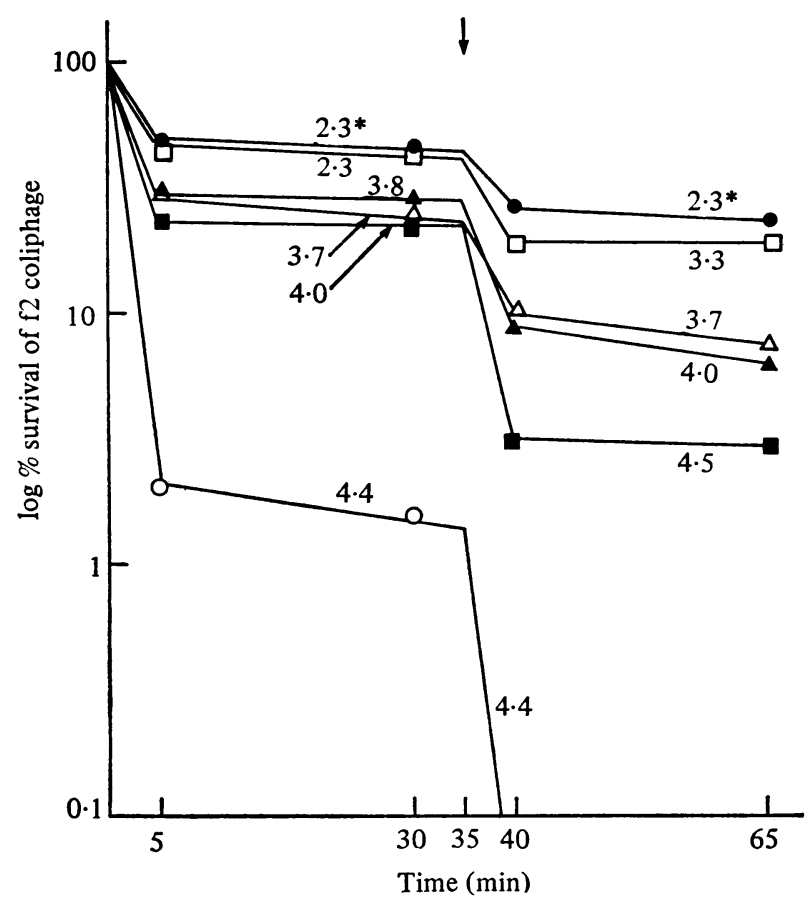

Fig. 5. Two-step chlorination of $\mathrm{f} 2$ coliphage in effluent at $\mathrm{pH} 6$ and $15{ }^{\circ} \mathrm{C}(22 \mathrm{mg} / 1$ organic matter in the medium). Arrow indicates time when second dose of chlorine was added. ${ }^{*}$ Chlorine residual $(\mathrm{mg} / \mathrm{l})$. 


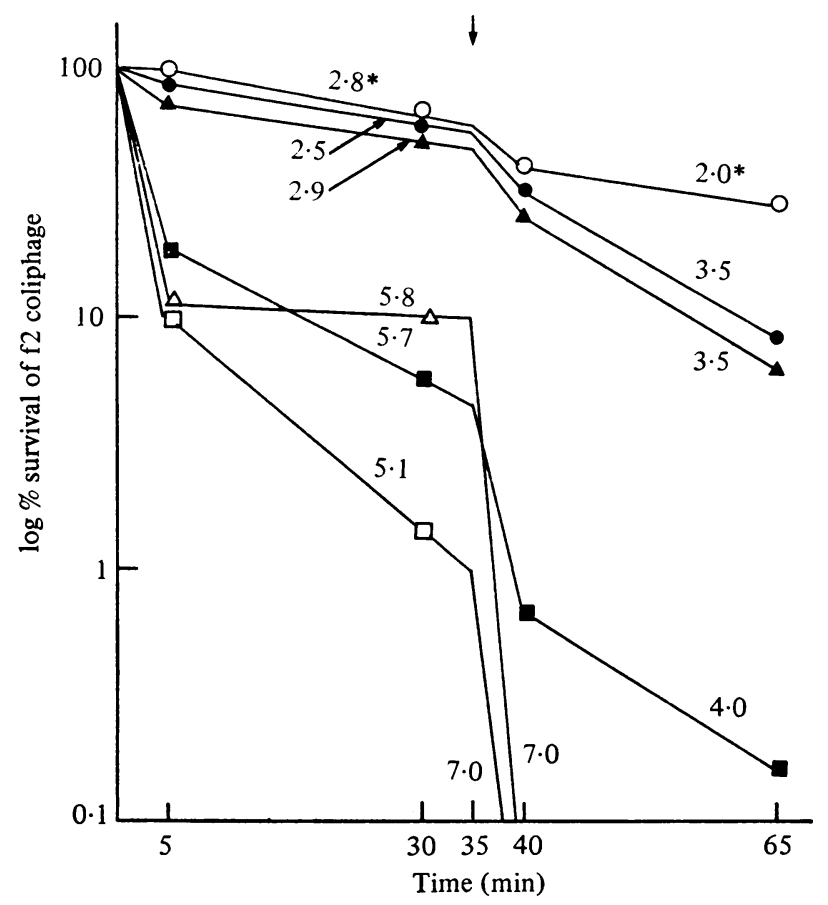

Fig. 6. Two-step bromination of $\mathrm{f} 2$ coliphage in effluent at $\mathrm{pH} 6$ and $15^{\circ} \mathrm{C}(22 \mathrm{mg} / \mathrm{l}$ organic matter in the medium). Arrow indicates time when second dose of $\mathrm{BrCl}$ was added. *Bromine residual (mg/l).

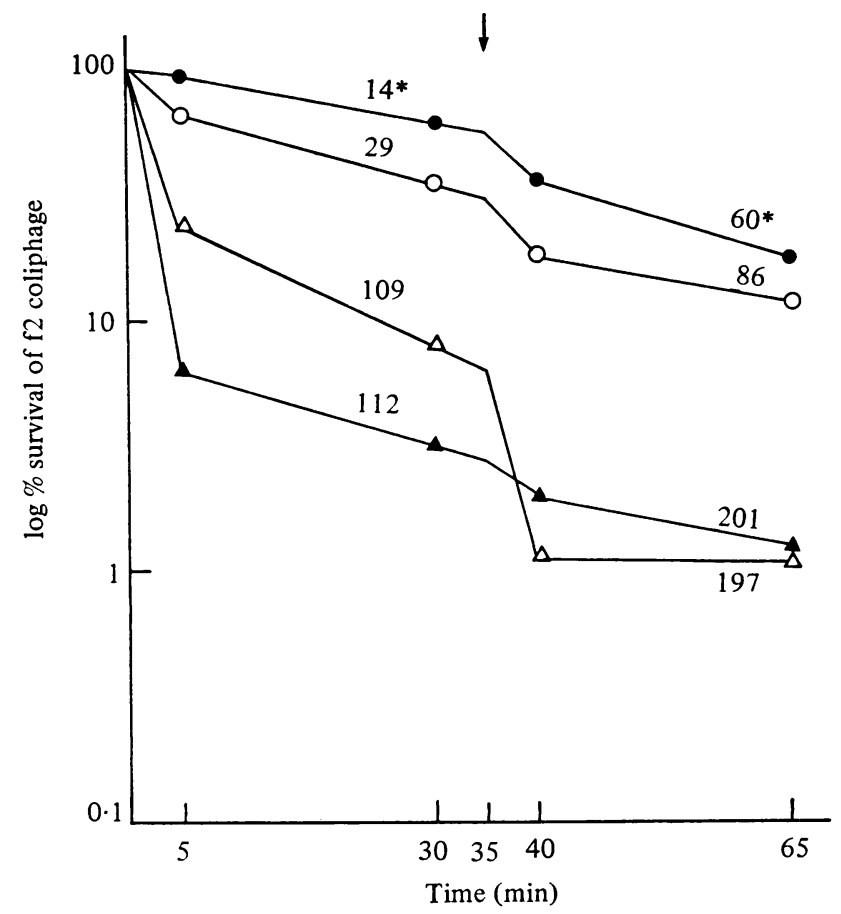

Fig. 7. Two-step disinfection of $\mathrm{f} 2$ coliphage in effluent with peracetic acid at pH 7.6 and $15^{\circ} \mathrm{C}(22 \mathrm{mg} / \mathrm{l}$ organic matter in the medium $)$. Arrow indicates time when second dose of peracetic acid was added. *Peracetic acid residual (mg/l). 
discharges and swimming pools, where the load of micro-organisms is expected to be high and extensive disinfection desirable, the use of two disinfectants may prove advantageous. Recently Wyatt \& Wilson (1979) reported that the use of ozone in conjunction with chlorine for swimming pool disinfection rendered the water bacteriologically safe.

Peracetic acid belongs to a different group of chemicals to the halogens but it exhibits a similar biphasic pattern of disinfection. It was interesting to note that effluent did not seem to have a demand for it; that is to say, unlike halogens, the concentration of peracetic acid did not decrease within 30 or 60 min contact time. Neither did its virucidal activity decrease after $30 \mathrm{~min}$. This was readily demonstrated by the addition of more coliphage, which was inactivated to the same degree as the original dose of coliphage. This was not the case with chlorine, where the second dose of virus was not inactivated, whether the residual was in the 'free' or 'combined' form of chlorine. The implications are that chlorine residual did not protect the effluent, as noted by Smith (1978).

It was also interesting to note that the two small doses of disinfectant added successively did not present any advantage over one equivalent large dose. This observation was in agreement with those of Krusé, Olivieri \& Kawata (1971) who achieved $1.5 \log$ reduction of $\mathrm{f} 2$ coliphage with a single dose of $30 \mathrm{mg} / \mathrm{l}$ chlorine or 3 doses of $10 \mathrm{mg} / \mathrm{l}$ each. The linear nature of the relation between concentration and degree of inactivation is thus apparent. The relative reduction in titres after each point of addition of disinfectant was the same whether, for instance, the initial titre was $1 \times 10^{5}$ p.f.u. $/ \mathrm{ml}$ or $8 \times 10^{3}$ p.f.u. $/ \mathrm{ml}$; that is to say, the percentage law applied.

Evidently, therefore, bromine chloride and peracetic acid had some distinct advantages over chlorine, but a cost-benefit estimation of their use might well prove that they would be too expensive to adopt as substitutes for chlorine in those instances where disinfection of effluent was required.

This work was supported in part by the Thames Water Authority.

\section{REFERENCES}

Balluz, S. A., Butler, M. \& Jones, H. H. (1978). The behaviour of $\mathrm{f} 2$ coliphage in activated sludge treatment. Journal of Hygiene 80, 237-42.

Brown, J. R., Mclean, D. M. \& Nixon, M. C. (1963). Bromine disinfection of swimming pools. Canadian Journal of Public Health 54, 267-70.

Chang, S. L. \& Morris, J. C. (1953). Elemental iodine as a disinfectant for drinking water. Industrial Engineering \& Chemistry 45, 1009-12.

Corn, L., Hannoun, C. \& Gomella, C. (1964). Inactivation par l'ozone du virus de la poliomyélite présent dans les eaux. Presse Médicale 72, 2153-7.

Evison, L. (1972). Inactivation of viruses in water with ozone. British Water Supply 9, 14-17.

Hajenian, H. \& Butler, M. (1980). Inactivation of viruses in municipal effluent by chlorine. Journal of Hygiene 84, 63.

Katzenelson, E. \& Biederman, N. (1976). Disinfection of viruses in sewage by ozone. Water Research 10, 629-31.

Keswich, B. H., Fujioka, B. H., Berbank, N. C. \& LoH, P. C. (1977). Bromine chloride: 
an alternative disinfectant to chlorine. Technical Memoranda Report No. 54, Office of Water Research and Technology, Washington, D.C., 15 pp.

Kurne, L. B. \& Hull, R. N. (1960). The virucidal properties of peracetic acid. American Journal of Clinical Pathology 33, 30-33.

Krusé, C. W., Olivieri, V. P. \& Kawata, K. (1971). The enhancement of viral inactivation of halogens. Water \& Sewage Worh's 118, 187-93.

Lothrop, L. \& Sproul, O. J. (1969). High-level inactivation of viruses in waste-water by chlorination. Journal of the Water Pollution Control Federation 41, 567-75.

McKee, J. E., Brokaw, C. J. \& McLaughlin, R. T. (1960). Chemical and colicidal effects of halogens in sewage. Journal of the Water Pollution Control Federation 32, 795-819.

Meyer, E. (1975). Disinfection von Abwasser aus Tierkorperbeseitigungsanstalten mit Hilfe der Peressigsäure. Sonderdruck aus Monatshefte für Veterinärmedizin 30, 368-71.

Mills, J. F. (1973). The chemistry of bromine chloride in waste water disinfection. Division of Environmental Chemistry, American Chemical Society 13, 137-41.

MILLs, J. F. (1975). Interhalogens and halogen mixtures as disinfectants. In Disinfection Water and Waste-water (ed. J. D. Johnson), pp. 113-43. Ann Arbor, Mich.: Ann Arbor Science Publishers.

Olivieri, V.P., Donovan, T. K. \& Kawata, K. (1971). Inactivation of virus in sewage. Journal of the Sanitary Engineering Division, PASCE 97, SA5, 661-73.

Painter, H. A. (1971). Chemical, physical and biological characteristics of wastes and waste effluents. In Water and Water Pollution Handbook, vol. I (ed. L. L. Ciaccio), pp. 329-64. N.Y.: Marcel Dekker.

Palin, A. T. (1950). A study of the chloro derivatives of ammonia and related compounds, with special reference to their formation in the chlorination of natural and polluted waters. Water and Water Engineering 54, 151-9, 189-200, 248-56.

Palin, A. T. (1957). The determination of free and combined chlorine in water by the use of diethyl-p-phenylene diamine. Journal of the American Water Works Association. 49, 873-80.

Pavoni, J., Tittlebaum, M., Spencer, H., Fleischman, M., Nebel, C. \& Gottschling, R. (1972). Virus removal from waste-water using ozone. Water and Sewage Works 119, $59-67$.

Perlman, P. G. (1969). Water resources engineering - technology briefs. Water and Wastes Engineering 6, 14.

Shuval, H. I., Cymbalista, S., Wachs, A., Zohar, Y. \& Goldblum, N. (1966). The inactivation of enteroviruses in sewage by chlorination. Advances in Water Pollution Research 2, 37-51.

SмrтH, J. W. (1978). Waste-water disinfectants : many called - few chosen. Water \& Wastes Engineering 15, 18-25.

Sprössig, M. \& MÜCKE, H. (1969). Die Virusdisinfektion durch Peressigsäure in Gegenwart von Alkoholen. Wissenschaftliche Zeitschrift der Humboldt-Universität zu Berlin, Math.Nat. 18, 1171-3.

Sully, B. D. \& Williams, P. L. (1962). The analysis of solutions of peracids and hydrogen peroxide. Analyst 87, 653-7.

TAYLOR, D. G. \& JoHnson, J. D. (1974). Kinetics of viral inactivation by bromine. In Chemistry of Water Supply, Treatment \& Distribution (ed. A. J. Rubin), pp. 368-408. Ann Arbor, Mich.: Science Publishers.

Tifft, E. C., Moffa, P. E., Richardson, S. L. \& Field, R. I. (1977). Enhancement of high rate disinfection by sequential addition of chlorine and chlorine dioxide. Journal of the Water Pollution Control Federation 49, 1652-8.

WARRINGER, T. (1967). Field tests on chlorination of poliovirus in sewage. Journal of the Sanitary Engineering Division, PASCE 93, SA5, 51-65.

WHITE, G. C. (1972). Handbook of Chlorination. N.Y.: Van-Nostrand Reinhold.

WyatT, T. D. \& WiLson, T. S. (1979). A bacteriological investigation of two leisure centre swimming pools disinfected with ozone. Journal of Hygiene 82, 425-41. 